\title{
ABDOMINAL ULTRASOUND - THE LEADING METHOD IN DUODENAL GIST DIAGNOSTICS
}

\author{
Sven Bohnec ${ }^{1}$, Ivan Budimir ${ }^{2}$, Davor Hrabar ${ }^{2}$, Nenad Babić ${ }^{3}$, Ivan Budimir Jr. ${ }^{4}$, \\ Marko Nikolić ${ }^{2}$ and Ivana Pavićs
}

${ }^{1}$ Gastroenterologie, Allgemeine Innere Medizin und Geriatrie, Rems-Murr Klinikum Winnenden, Winnenden, Germany; ${ }^{2}$ Department of Gastroenterology, Clinical Department of Internal Medicine; ${ }^{3}$ Division of Radiology, Sestre milosrdnice University Hospital Center, School of Medicine and School of Dental Medicine, University of Zagreb, Zagreb; ${ }^{4}$ Magdalena Hospital for Cardiovascular Diseases, Osijek School of Medicine, Krapinske Toplice; ${ }^{5}$ Department of Pathology, Sestre milosrdnice University Hospital Center, School of Medicine and School of Dental Medicine, University of Zagreb, Zagreb, Croatia

SUMMARY - Gastrointestinal stromal tumors (GIST) are the most common mesenchymal tumors of the digestive tract and are generally asymptomatic. A 39-year-old female patient was hospitalized in 2012 at Clinical Department of Internal Medicine, Sestre milosrdnice University Hospital Center, for a focal hypodense irregular circular lesion located in segment III of the left hepatic lobe, accidentally found by ultrasonography and verified by computed tomography. The findings were also verified with nuclear magnetic resonance and esophagogastroduodenoscopy. A biopsy sample of the lesion was analyzed by histologic and immunohistochemical methods and identified as GIST. The patient underwent surgical operation (tumor excision with terminoterminal anastomosis created between the second segment of duodenum and jejunum and resection of liver segment III). The histopathologic findings matched GIST with a high probability of relapse according to the localization, size, mitotic activity and Ki-67 values. Therefore, therapy with imatinib at a dose of $400 \mathrm{mg} / \mathrm{day}$ was administered. Three years after the operation, the patient is still in remission.

Key words: Gastrointestinal stromal tumors - diagnostic imaging; Ultrasonography; Elasticity imaging techniques; Imatinib mesylate; Case reports

\section{Introduction}

Gastrointestinal stromal tumors (GISTs) are the most common mesenchymal tumors of the digestive tract and are generally asymptomatic, but they make only $1 \%$ of primary tumors of the gastrointestinal (GI) tract. GISTs are usually accidentally found during endoscopic or radiologic procedures. After immunohistochemical analysis, Hirota et al. ${ }^{1}$ discovered connection between GIST and Cajal intestinal cells and their predecessors. The incidence of GIST is 6.8-14.5/ million $^{2-5}$, it occurs at a median age of 63 and men are

Correspondence to: Sven Bohnec, MD, Gertrud-Bäumer-Allee 13, 71364 Winnenden, Germany

E-mail: svenbohnec@gmail.com

Received December 16, 2015, accepted October 20, 2016 affected more commonly (55\%). In $80 \%$ of cases, a KIT-gene mutation is found, $15 \%$ are considered as a wild-type mutation and 5\% are KIT-negative PDFRA-positive mutation ${ }^{6}$. The two most common primary sites are stomach (60\%-75\%) and small intestine (20\%-30\%). GIST shows extraluminal growth, but it does not infiltrate local organs. About 10\%-25\% of patients have metastases, most common in the liver and peritoneum. Diagnostic algorithm consists of multi-slice computed tomography (MSCT), magnetic resonance imaging (MRI), ultrasonography, endoscopic ultrasonography, positron emission tomography-computed tomography (PET CT), histopathologic and immunohistochemical methods. Primary treatment is surgical procedure with adjuvant pharmacotherapy with imatinib. 


\section{Case Report}

A 39-year-old female patient treated for iron-deficiency anemia since 2006 was hospitalized in 2012 at Clinical Department of Internal Medicine, Sestre milosrdnice University Hospital Center. She came from another facility for planned aspiration biopsy of CTverified focal hypodense irregular circular lesion with an approximately $3-\mathrm{cm}$ diameter located in segment III of the left hepatic lobe. Transabdominal ultrasound (Fig. 1a, b) revealed a tumorous ring-shaped lesion, in addition to prior CT-verified lesion, with a diameter

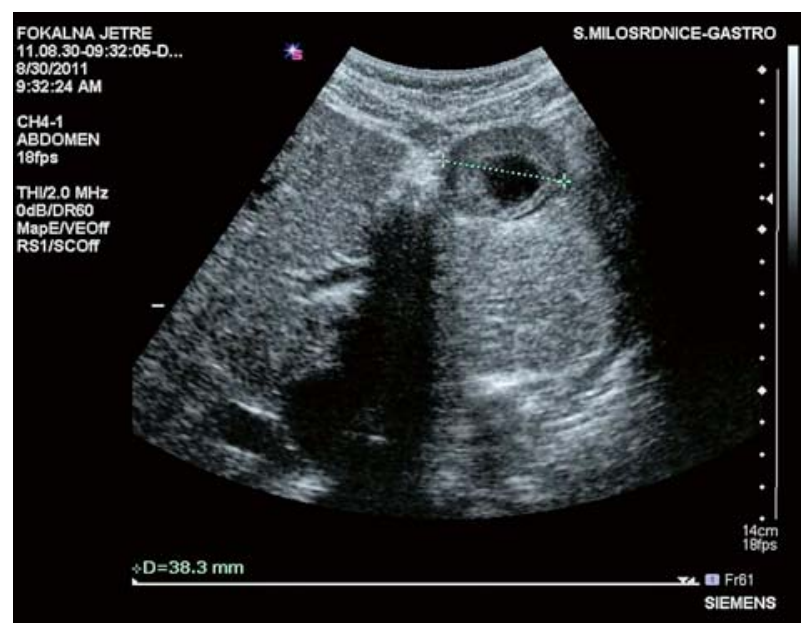

Fig. 1a. Upper abdomen ultrasonography showing an irregularly round focal hypoechoic lesion, $38 \mathrm{~mm}$ in diameter, and a ventral anechoic area in the left hepatic lobe.

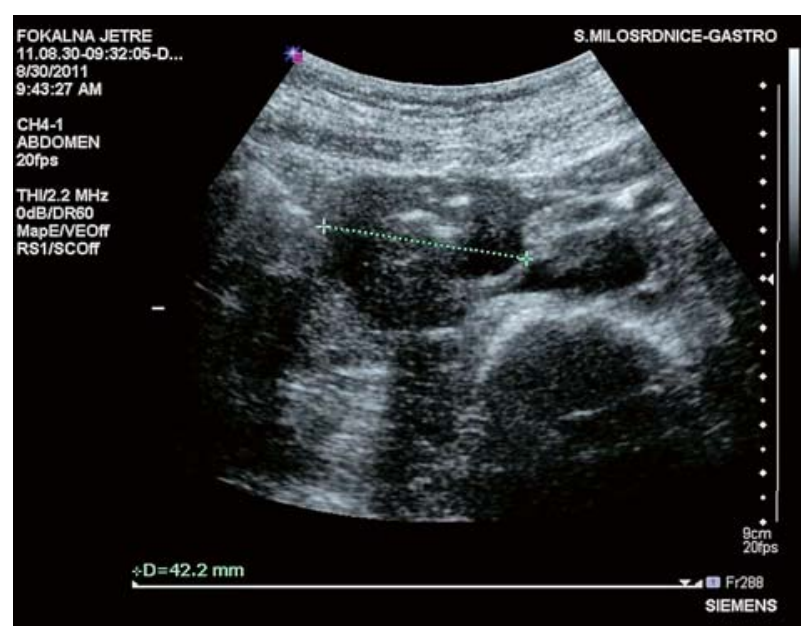

Fig. 1b. Upper abdomen ultrasonography showing a ring-shaped tumor mass, $42 \mathrm{~mm}$ in diameter, paravertebrally right. of $42 \mathrm{~mm}$ on the right paravertebral side in the projection of the duodenum, which was confirmed by nuclear MRI (Fig. 2a, b). Her symptoms in the past 6 months were postprandial pain in the right upper quadrant and weight loss (5 kg). She had slightly lower hemoglobin, hematocrit and mean corpuscular volume (MCV) with slightly elevated alfa 1 protein in plasma electrophoresis. Esophagogastroduodenoscopy (EGD) of the postbulbar duodenal segment (transition between segment II and segment III) was performed and showed a circular yellowish proliferative lesion which narrowed down the lumen to about 10 $\mathrm{mm}$. A biopsy sample of the lesion was analyzed by histologic and immunohistochemical methods and identified as GIST (Fig. 3a, b). An operation was per-

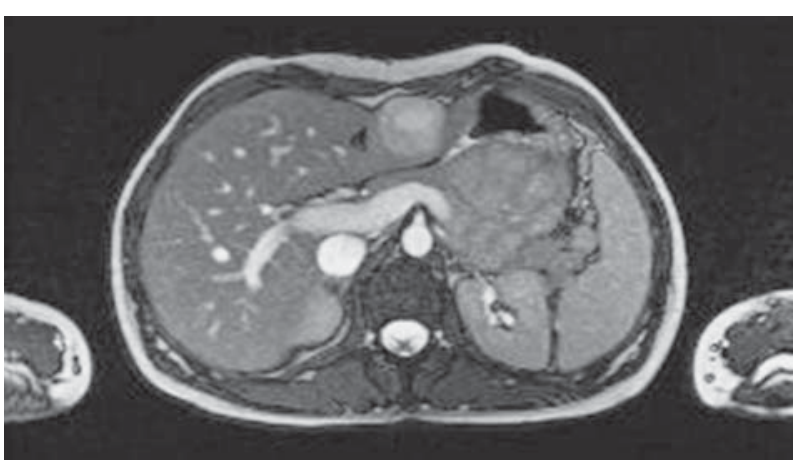

Fig. 2a. Nuclear magnetic resonance imaging of the abdomen showing an expansive mass, $32 \mathrm{~mm}$ in diameter, in the left hepatic lobe (border of the $2^{\text {nd }}$ and $3^{\text {rd }}$ segment), which caused deformity of the liver and had high intensity T2 signal centrally (necrosis or liquid content).

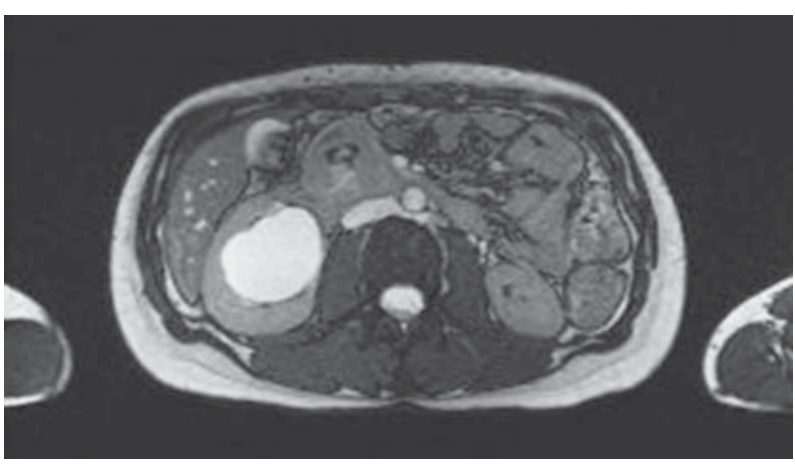

Fig. 2b. Nuclear magnetic resonance imaging of the abdomen: in the projection of the first part of duodenum, the wall is thickened $(10-20 \mathrm{~mm})$ and has irregular shape with transverse diameter of $45 \mathrm{~mm}$; on the right, parapielic cyst with diameter of $50 \mathrm{~mm}$. 


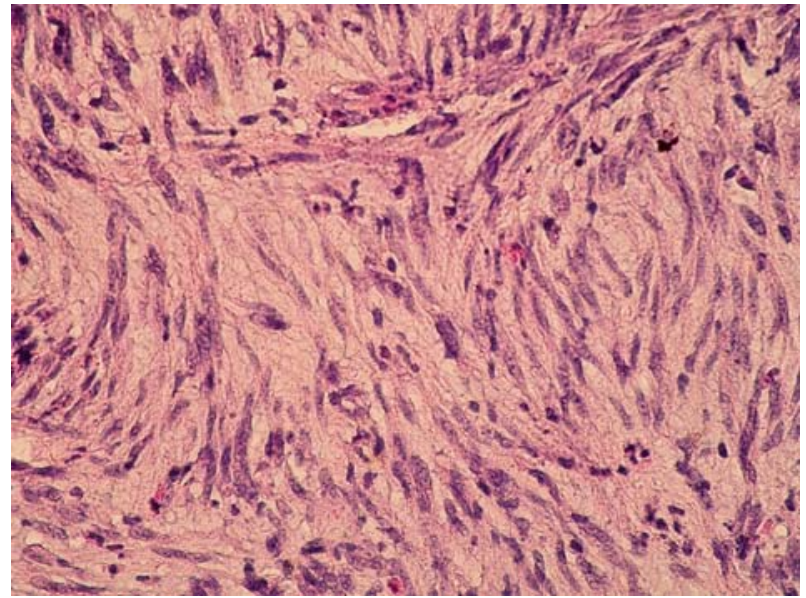

Fig. 3a. Part of the tumor mass that contains elongated cells with pale eosinophilic cytoplasm, elongated nuclei and partly present perinuclear vacuoles located at the poles of the nuclei; 17 mitoses per $50 \mathrm{HPF}$. (HE, X400)

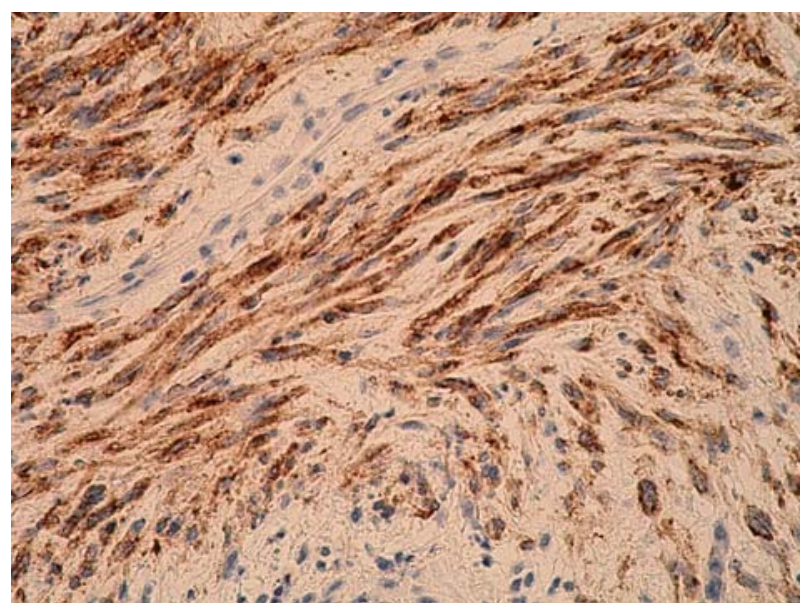

Fig. 3b. Histologic image of tumor mass on immunohistochemical procedure (CD117+, CD34+, PDGFr-, S100-, SMA-, desmin-). (CD 117, X400)

formed $(5 \mathrm{~cm}$ large tumor excision and resection of segment III, segment IV and partial resection of distal segment II of duodenum with terminoterminal anastomosis created between second segment of duodenum and jejunum and resection of liver segment III). The histopathologic findings matched GIST with a high probability of relapse according to the localization, size, mitotic activity and Ki-67 values. Therefore, therapy with imatinib at a dose of $400 \mathrm{mg} /$ day was administered. Three years after the operation, the patient is still in remission.

\section{Discussion}

Abdominal ultrasonography and EGD are mentioned as primary diagnostic methods in GIST diagnostics. They are usually performed because of abdominal pain or palpable masses within the abdomen. When the initial suspicion of GIST is set, MSCT is the main imaging method for diagnosing both primary tumor and possible metastases, but sometimes GIST can be suspected just on ultrasonography. PET CT can be useful in determining hidden metastases ${ }^{7}$, but GIST may be present without significant metabolic activity. EGD is used to describe tumor morphology, possible strictures in the GI tract, and to take biopsy samples. In our case, postbulbar duodenum was infiltrated with a circular, yellowish lesion which narrowed it to $0.8 \mathrm{~cm}$. Endoscopic ultrasonography (EUS) is the best method to differentiate GIST from leiomyoma. Leiomyoma and GIST have their origin in the $2^{\text {nd }}$ and $4^{\text {th }}$ hypoechoic layer, respectively. GIST has distorted shape, lobulation, irregular borders and increased echogenicity in comparison with the surrounding muscle echo, inhomogeneous pattern (inhomogeneity, hyperechoic posts, anechoic area), marginal halo and extraluminal growth pattern. Other signs that indicate malignancy are tumors bigger than $3 \mathrm{~cm}$ with irregular edges. In addition to EUS, EUS elastography with dominantly quantitative analysis (relatively heterogeneous 'hard' appearance without display of areas of necrosis by elastography software) can be performed and the strain ratio index measured. GIST has a high strain ratio index and therefore cannot be compressed. Contrast-enhanced EUS (CE-EUS) can demonstrate perfusion characteristics of subepithelial lesion and therefore can be used to differentiate GIST from other benign tumors (lipoma or leiomyoma) based on the hyper-enhanced appearance of GIST. CE-EUS has been recently used for assessment of tumor vascularity in order to predict the preoperative malignancy risk of GISTs through identification of irregular vessels. With the EUS method, safe thin-needle biospy can be performed ${ }^{8}$ to obtain samples for histopathologic and molecular analysis. Table 1 shows complete histologic analysis of GIST.

After that, classification of stages and risk determination according to one of the classifications must be done. All these classifications have a purpose to determine high, intermediate or low risk GIST. According 
Table 1. Complete histologic analysis of gastrointestinal stromal tumors

\begin{tabular}{|l|l|}
\hline Content of histologic analysis & Our patient \\
\hline $\begin{array}{l}\text { Diagnosis and classification according } \\
\text { to histologic cell type }\end{array}$ & Spindle cell \\
\hline Size of tumor & $5 \mathrm{~cm}$ \\
\hline $\begin{array}{l}\text { Position (infiltration in mucosa } \\
\text { or serosa, rupture) }\end{array}$ & $\begin{array}{l}\text { Infiltration } \\
\text { in mucosa }\end{array}$ \\
\hline Number of mitoses/50 VVP & $15 / 50$ \\
\hline Proliferation index (Ki in \%) & $17 \%$ \\
\hline $\begin{array}{l}\text { c-KIT (focal/diffuse positive, negative, } \\
\text { dot-like positive in cytoplasm) }\end{array}$ & $\begin{array}{l}\text { Diffuse/ } \\
+(\text { positive) }\end{array}$ \\
\hline DOG1 (focal/diffuse positive, negative) & - (negative) \\
\hline CD34 (focal/diffuse positive, negative) & $\begin{array}{l}\text { Diffuse/ } \\
+(\text { positive) }\end{array}$ \\
\hline Desmin (focal/diffuse positive, negative) & -(negative) \\
\hline SMA (focal/diffuse positive, negative) & -(negative) \\
\hline S-100 (focal/diffuse positive, negative) & -(negative) \\
\hline Ki-67 (\% of positive cells) & $17 \%$ \\
\hline
\end{tabular}

to the US National Institutes of Health, $44 \%$ of GIST are high risk, 23.6\% intermediate risk and 32.4\% low risk. In our case, the patient was classified in the high risk group.

Treatment of GIST is multidisciplinary through cooperation of surgeon, pathologist and oncologist ${ }^{9,10}$. Complete surgical removal is recommended. In the treatment of inoperable or metastatic GIST, imatinib at a dose of $400 \mathrm{mg} /$ day is used. In case of disease progression, the dose can be increased to $800 \mathrm{mg} /$ day of imatinib. In patients with high and intermediate risk GIST, $400 \mathrm{mg} /$ day imatinib therapy is recommended, as in our patient. In patients with inoperable or metastatic imatinib-resistant GIST, sutinib ${ }^{11}$ can be used as second line therapy. There are other promising drugs in clinical trials such as nilotinib, masitinib, dasatinib, sorafenib, vatalanib and combination of imatinib with RAD001-everolimus ${ }^{12,13}$.

\section{Conclusion}

Gastrointestinal stromal tumors are rare tumors of the gastrointestinal tract, which account for only $1 \%$ of all primary tumors of the GI tract ${ }^{14,15}$, and they are often diagnosed accidentally. Initial suspicion of GIST can be set by ultrasonography, but the main diagnostic methods are MSCT and EUS ${ }^{16}$.

\section{References}

1. Hirota S, Isozaki K, Moriyama Y. Gain-of-function mutations of c-kit in human gastrointestinal stromal tumors. Science. 1998;279:577-80.

2. Nilsson B, Bumming P, Meis-Kindblom JM. Gastrointestinal stromal tumors: the incidence, prevalence, clinical course, and prognostication in the preimatinib mesylate era - populationbased study in western Sweden. Cancer. 2005;103:821-9.

3. Tryggvason G, Gislason HG, Magnusson MK, Jonasson JG. Gastrointestinal stromal tumors in Iceland, 1990-2003: the Icelandic GIST study, a population-based incidence and pathologic risk stratification study. Int J Cancer. 2005;117:289-93.

4. Goettsch WG, Bos SD, Breekveldt-Postma N. Incidence of gastrointestinal stromal tumors is underestimated: results of a nation-wide study. Eur J Cancer. 2005;41:2868-72.

5. Tran T, Davila JA, E1-Serag HB. The epidemiology of malignant gastrointestinal stromal tumors: an analysis of 1458 cases from 1992 to 2000. Am J Gastroenterol. 2005;100:162-8.

6. Joensuu H. Gastrointestinal stromal tumor (GIST). Ann Oncol. 2006;17(Suppl 10):280-6.

7. Demetri GD, Benjamin RS, Blanke CD, et al. NCCN task force report: Optimal management of patients with gastrointestinal stromal tumor (GIST) - Update of NCCN Clinical Practice Guidelines. J Natl Comp Cancer Net. 2007;5(2 Suppl):S1-29.

8. Tio TL, Tytgat GN, den Hartog Jager FC. Endoscopic ultrasonography for the evaluation of smooth muscle tumors in the upper gastrointestinal tract: an experience with 42 cases. Gastrointest Endosc. 1990;36:342-50.

9. Casali PG, Jost L, Reichardt P, et al. Gastrointestinal stromal tumors: ESMO Clinical Recommendations for diagnosis, treatment and follow-up. Ann Oncol. 2009;20(Suppl 4):iv64-iv67. doi:10.1093/annonc/mdp 131

10. NCCN Clinical Practice Guidelines in Oncology. Soft Tissue Sarcoma V.2.2010 Source: www.ncen.org.

11. Faivre S, Delbaldo C, Vera K. Safety, pharmacokinetic, and antitumor activity of SU11248, a novel oral multitarget tyrosine kinase inhibitor in patients with cancer. J Clin Oncol. 2006; 24(1):25-35.

12. Blay JY. A decade of tyrosine kinase inhibitor therapy: historical and current perspectives on targeted therapy for GIST. Cancer Treat Rev. 2010. doi:10.1016/j.ctrv.2010.11.003.

13. Joensuu H, Trent CJ, Reichardt P. Practical management of tyrosine kinase inhibitor-associated side effects in GIST. Cancer Treat Rev. 2011;37:75-8.

14. Miettinen M, Lasota J. Gastrointestinal stromal tumors - definition, clinical, histological, immunohistochemical, and molecular genetic features and differential diagnosis. Virchows Arch. 2001;438:1-12.

15. Miettinen M, Sarlomo-Rikala M, Lasota J. Gastrointestinal stromal tumors: recent advances in understanding of their biology. Hum Pathol. 1999;30:1213-20.

16. Croatian guidelines for diagnosis, treatment and follow-up of patients with gastrointestinal stromal tumors. Lijec Vjesn. 2011 May-Jun;133(5-6):170-6. 
Sažetak

\title{
ULTRAZVUK ABDOMENA - VODEĆA METODA U DIJAGNOSTICI GIST-a DUODENUMA
}

\author{
S. Bohnec, I. Budimir, D. Hrabar, N. Babić, I. Budimir ml., M. Nikolić i I. Pavić
}

Gastrointestinalni stromalni tumori (GIST) najčešći su mezenhimni tumori probavnog trakta i najčešće su asimptomatski. Naša 39-godišnja bolesnica hospitalizirana je 2012. godine na Klinici za internu medicinu KBC-a Sestre milosrdnice zbog ultrazvučno slučajno nađene i kompjutorskom tomografijom potvrđene hipodenzne nepravilne okrugle lezije lokalizirane u 3. segmentu lijevog jetrenog režnja. Nalaz je potvrđen magnetskom rezonancijom i ezofagogastroduodenoskopijom. Histološkim i imunohistološkim metodama obrade uzorak biopsije se identificirao kao GIST. Učinjena je primarna resekcija (potpuna ekscizija tumora s terminoterminalnom anastomozom između II. odsječka dvanaesnika i jejunuma i resekcijom 3. segmenta jetre). Patohistološki nalaz je potvrdio dijagnozu GIST-a, a s obzirom na lokalizaciju, veličinu, mitotsku aktivnost i vrijednosti Ki-67 tumor je svrstan u skupinu visokorizičnih za recidiv. Zbog toga je indicirana terapija imatinibom u dozi od $400 \mathrm{mg} / \mathrm{dan}$. Tri godine nakon operacije bolesnica je i dalje u remisiji.

Ključne riječi: Gastrointestinalni stromalni tumori - dijagnostika; Ultrazvuk; Elastografski slikovni prikaz; Imatinib mesilat; Prikazi slučaja 